\title{
Analyzing the Determinants of Individual Action on Climate Change by Specifying the Roles of Six Values in South Korea
}

\author{
Seol-A Kwon ${ }^{1}$, Seoyong Kim ${ }^{2, *}$ and Jae Eun Lee ${ }^{3, *}$ \\ 1 National Crisis and Emergency Management Research Institute, Chungbuk National University, \\ Chungdae-ro 1, Seowon-Gu, Cheongju, Chungbuk 28644, Korea; seolakwon@chungbuk.ac.kr \\ 2 Department of Public Administration, Ajou University, Worldcup-ro, Suwon 16499, Korea \\ 3 Department of Public Administration, Chungbuk National University, Chungdae-ro 1, Seowon-Gu, \\ Cheongju, Chungbuk 28644, Korea \\ * Correspondence: seoyongkim@ajou.ac.kr (S.K.); jeunlee@chungbuk.ac.kr (J.E.L.)
}

Received: 13 February 2019; Accepted: 22 March 2019; Published: 27 March 2019

\begin{abstract}
The serious problems stemming from climate change require an active response it. This study focuses on the role of value factors in action on climate change. Individuals' values systematically influence the fundamental orientation of their attitudes and behaviors. Therefore, this study analyzes whether six values, namely: ideology, environmental justice, religiosity, personal norms, scientific optimism, and environmentalism, influence action on climate change directly or indirectly, and compares their effects with perception factors' impact. The results indicate that religiosity decreased action on climate change, whereas personal norms, science and technology (S\&T) optimism, and environmentalism increased such action. Among the perception factors, perceived risks and benefits, trust, and knowledge increased action on climate change. Furthermore, perception factors explained action on climate change more than value factors did. Moreover, value factors (i.e., S\&T optimism and environmentalism) moderated the impacts of perceived risks, perceived benefits, and negative emotions on action against climate change.
\end{abstract}

Keywords: action on climate change; value; perception; ideology; environmental justice; religiosity; personal norm; environmentalism; science and technology optimism; perceived risk and benefit; trust; knowledge; emotion

\section{Introduction}

According to the Intergovernmental Panel on Climate Change [1], climate change is occurring at an unprecedented speed in the history of modern civilization. Additionally, climate change has led to the emergence of several new hazards, such as new diseases, viruses, and pests. Moreover, climate change has a discriminatory influence on the most vulnerable groups of human civilization [2] (p. 388).

Various efforts and adaptation programs have been implemented at the country and local levels to address the problem of climate change. At the country level, climate change is a complicated political issue, which requires high levels of trust and cooperation among countries to resolve it. The "Multilingual Summaries Climate Change Mitigation 34 Policies" and "Progress Report" released by the Organization for Economic Cooperation and Development [3] showed that its member states, the European Union, and ten partner countries (Brazil, China, Colombia, Costa Rica, Indonesia, India, Latvia, Lithuania, Russia, and South Africa) have made substantial progress in the implementation of policies to mitigate climate change. Additionally, actions to address climate change have been implemented in developing countries. For example, among African countries, Uganda has established policies to deal with climate change despite difficulties such as (1) limitations in technical capabilities 
related to policy responses and actions at the state level, (2) financial and political interference, and (3) the lack of a functional implementation structure for policies related to climate change [4] (p. 81).

One example of actions on climate change is a carbon emissions trading system. This policy has been adopted by not only national but also local governments. Members of the European Union and other countries, such as South Korea, New Zealand, and Switzerland, have adopted carbon trading systems at the national level. China introduced pilot projects for carbon emissions trading in seven cities and provinces, and it plans to introduce them throughout the country. At the local level, California and nine northeastern states in the US, Quebec in Canada, along with Tokyo and Saitama in Japan have implemented carbon trading systems. Based on the Action Plan created in the 1992 Rio Earth Summit's Agenda 21, local governments in Denmark made efforts for climate change mitigation through immediate action by establishing Local Agenda 21 [5] (p. 75).

The world has focused on responding to climate change at the national and local levels. However, the success of climate change policies does not depend fully on international organizations and central or local governments. Individuals who personally take action on climate change are key agents as well. Recently, new climate change policies focus on individuals' behavioral roles and commitments. Decisive actions by individuals can be used as tools and resources to solve present climate change problems. Accordingly, it is important to understand the factors that determine or cause individuals' actions on climate change [6].

Various approaches can be used to understand individuals' thought and actions on climate change. First, the environmental awareness approach focuses on strengthening individuals' wills to act on climate change. This approach assumes that awareness of climate change problems motivates positive attitudinal changes. Several studies have examined this assumption. For example, Marshall et al. [7] reported that within Australian peanut producers, the role of climate change awareness influences adaptive capacity, which is the human potential to convert existing resources into successful adaptation strategies. Adebayo et al. [8] demonstrated that the majority of the farmers in the state are aware of climate change and admit that climate change has affected their farming activities in recent years. This awareness induces the farmer to make efforts on adaptation to climate change. After Lorenzoni et al. [9] argued that awareness and concern about climate change can be translated into personal engagement as an action for reducing carbon dependency. Also, they showed that there are various barriers or constraints for participants to engage in action on climate change. "Individual barriers include: lack of knowledge; uncertainty and skepticism; distrust in information sources; externalizing responsibility and blame; reliance on technology; climate change perceived as a distant threat; importance of other priorities; reluctance to change lifestyles; fatalism; and helplessness. Social barriers are subdivided into: lack of action by governments, business and industry; 'free rider effect'; pressure of social norms and expectations; and lack of enabling initiatives (p. 449)". Schultz and Oskamp [10] found a strong positive relationship between attitudes of environmental concern and the amount of effort they were willing to exert to recycle. Skalík et al. [11] showed that the more students were informed about the climate change problem, the more they felt their personal responsibility for climate change. When Mase et al. [12] examined how farmers' belief in anthropogenic climate change, perceptions of changing weather patterns, and climate risks influences their attitudes toward adaption. Perception of risk to their own farm is the most important determinants of adaptation. Nordlund and Garvill [13] demonstrated that not only value but also problem awareness influences personal norm, which in turn influences willingness to reduce personal car use. According to Spence et al. [14], those who report experience of flooding express more concern over climate change, and feel more confident that their actions will have an effect on climate change. Those perceptions bring out a greater willingness to save energy to mitigate the climate change.

In short, the awareness approach aims to induce individuals' active actions by helping them learn about the ecological and social impacts of climate change [15].

Second, the communication approach focuses on information sources and media. Spence et al. [16] examined how information on symbolic images related to climate change (e.g., glacier recordings) 
motivates public action on climate change. This approach examines effective modes of information provision as well as ways of building trust, creating continuous action, and facilitating effective cooperation among various stakeholder groups, all of which are assumed to facilitate the public's communication and participation in action on climate change [15].

Third, the perception approach highlights the subjective judgment of risk. Visschers and Siegrist [17] grouped research on risk into two categories: First, based on the psychometric paradigm, explains variations in perceptions of different risks whereas second examines the factors determining an individual's perception of a risk (i.e., perceived benefits, trust, knowledge, affective association, values, and fairness). Frondel et al. [18] reported that the determinants of an individual's risk perception regarding climate change are associated with three kinds of natural hazards: heat waves, storms, and floods.

Lastly, the value approach assumes that values play a significant role in climate change debates. Specifically, it purports that adaptation to climate change depends on the values underlying individuals' notions of what the goals of adaptation should be [19]. Furthermore, it assumes that individuals' decisions are influenced not only by their perceptions of significant benefits and risks, but also by moral concerns [20].

Among these four approaches, we adopt the value approach. Accordingly, our study focuses on how the value structures of individuals influence their actions on climate change. Specifically, we compare the explanatory power of six values with that of perceptions. We focus on values because, although perception factors are important in individuals' assessments of the need for action on climate change, the values underlying these perceptions have crucial direct or indirect impacts on action against climate change. However, whereas a lot of studies have focused on risk perception [21-24], several studies [25,26] have examined the role of different kinds of values in action on climate change. For example, based on the value-belief-norm theory (VBN) developed by Stern and colleagues [27], Rehead et al. [28] showed that the pre-defined value orientations, e.g., paradoxical concern, human-centric concern, and biospheric concern, induced environmental attitudes related with climate change. Nilsson et al. [29] showed that environmental values were important factors influencing the willingness to accept the policy measures for climate change. Also, Jansson and Dorrepaal [30] showed that the moral foundations concerning harm and fairness are positively associated with personal norms on climate change. The next section presents a review of the literature on value and risk perception factors and the research hypothesis.

\section{Theoretical Background}

\subsection{Value Versus Risk Perception}

Studies on climate change can be divided into two categories: those examining values and those examining risk perception. All environmental attitudes and actions are closely related to a set of human values and perceptions that go beyond such issues as ecosystem protection and resource conservation [31]. However, studies on values and perceptions as determinants of action on climate change have utilized different perspectives.

First, several studies have focused on the power of values in environmental action [32-34]. Rokeach [35] (p. 5) defined a value as "an enduring belief that a specific mode of conduct or end-state of existence is personally or socially preferable to an opposite or converse mode of conduct or end-state of existence." Behavioral responses to climate change generally tend to be activated when the basic values and norms of society are threatened. Factors leading to resistance or behavior against an object arise from the recognition and understanding of more fundamental value factors, such as ethical responsibility, political factors, and human needs in complex modern society. Wolf et al. [26] explained that values are an important factor that shapes perceptions regarding the impact of climate change and an individual's adaptation to it. Douglas [36,37], anthropologist, argued that values and worldviews play important roles in risk perception and behavior. Social, cultural, and political attitudes 
toward the world play major roles in eliciting individual reactions and behaviors in complex social phenomena. According to her argument, different cultural values elicit different tendencies when risks and policies are perceived differently. Based on the values underlying their cultural biases, cultural studies classify individuals into the following four categories: hierarchists, individualists, egalitarians, and fatalists [38,39]. Bellamy and Hulme [40] empirically showed that egalitarians exhibited more concern about climate change than did individualists and fatalists.

Studies on climate change have utilized the value approach to test the role of the following value sets empirically: ideology, religiosity, personal norms, science and technology (S\&T) optimism, environmental justice, and environmentalism. For example, conservative political ideology is consistently associated with greater climate change skepticism [22]. Truelove and Joireman [41] demonstrated that religiosity influences action on climate change. According to Nilsson et al. [29], personal norms are consistently related with willingness to accept climate change policies. Kim and Kim [34] reported that perceived environmental injustice and S\&T optimism increase action on climate change. Moreover, pro-environmental values are associated with willingness to engage in climate change mitigation actions [22].

Second, the risk perception approach focuses on perception factors, such as perceived risks, perceived benefits, trust, knowledge, and negative emotional image. Perception matters because it provides the basic means for recognizing, evaluating, and understanding the risk. In the seminal research of Fischhoff et al. [42], the degree of risk was identified as a subjective rather than an objective construct. According to Jankó et al. [43], perception is related to attitudes, decision-making, and communication and, thus, affects both formal and informal behavior. Perception research has identified differences in cognition mechanisms between groups. For example, compared to the expert group (the scientific community), the general public has been found to be affected more by limitations in perceptions and visibility. This difference in perception could lead to cognitive bias [44]. Johnson [45] found that expanding perceptions and knowledge acquired through increasing environmental expertise, awareness, and social networks could improve citizens' motivation to solve environmental problems related to climate change.

The differences between the value and risk perception approaches are presented in Table 1. Values are discussed across various disciplines, whereas risk perception is studied mainly by researchers focusing on risk communication. The former cannot be changed within a short period, especially with reference to external stimuli, whereas the latter is relatively easy to change in general. Furthermore, a change in values requires generational change or deep experiences. Moreover, fundamental values have consistent and stable relationships with other variables, whereas versatile perceptions are inconsistent and variant.

Table 1. Comparison of the value and risk perception paradigms.

\begin{tabular}{|c|c|c|}
\hline & Value Paradigm & Risk Perception Paradigm \\
\hline Discipline & $\begin{array}{c}\text { Anthropology, sociology, } \\
\text { psychology, political science }\end{array}$ & Risk communication \\
\hline Key variable (in this study) & $\begin{array}{l}\text { Ideology, environmentalism, } \\
\text { religiosity, personal norm, S\&T } \\
\text { optimism, and environmentalism }\end{array}$ & $\begin{array}{l}\text { Perceived benefits, perceived risks, } \\
\text { stigma, trust, and knowledge }\end{array}$ \\
\hline Level of depth/Structure & Deep/Structured & Shallow/Structuration \\
\hline Possibility of change & Difficult/Generational change & Easy/Stimuli \\
\hline Time perspective & Long & Short \\
\hline $\begin{array}{l}\text { Impact and relationships with } \\
\text { other variables }\end{array}$ & $\begin{array}{c}\text { Strong and } \\
\text { consistent/Context-dependent }\end{array}$ & $\begin{array}{c}\text { Weak and } \\
\text { inconsistent/Context-free }\end{array}$ \\
\hline Limitation & False consciousness & Cognitive bias \\
\hline
\end{tabular}


Although values and perceptions are intertwined with each other, the former critically influences the latter. Kahan et al. [46] suggested the cultural cognition perspective, in which individuals tend to form perceptions toward societal risk that cohere with the value characteristics of groups with which they identify. According to Prati et al. [47], values such as universalism, self-direction, and hedonism are associated with risk perception related to climate change. Wolf et al. [26] demonstrated the effect of activated values on the perception of unusual climate change events. Value-centered approaches consider perceptions to comprise the value that individuals assign to different objects [25]. Based on this discussion, we consider values to be the main factor influencing perceptions regarding action on climate change.

\subsection{Value Factors}

\subsubsection{Ideology}

Ideology, as a political belief, is one of the concepts that fundamentally influence social groups' perceptions of social phenomena, systems, and social structure. Based on political beliefs, it is possible to explain and predict social phenomena logically and consistently. Liberals and conservatives have different perspectives on climate change.

Political ideology in response to climate change is closely related to issues such as preferences for the market regulation and the paradigm of economic growth. In general, those with positive attitudes toward economic growth and negative attitudes toward market regulation tend to be passive in responding to climate change [48]. Conservatives engage in environmental activities pertaining to climate change for the sake of their own power and self-preservation. Thus, they inevitably work to protect the environment to preserve their own survival and permanence.

On the other hand, liberals view climate change from the issues of the coexistence between people and the environment, not merely of chaos or problems [49]. Empirical studies by Hamilton and Keim [32], McCright and Dunlap [33], and Borick and Rabe [50] showed that the impact of political beliefs on climate change is very significant. They showed that in the US, Democrats have been more concerned about climate change and global warming and more active in their responses to climate change than Republicans have been. In other words, liberals have more serious attitudes toward climate change than do conservatives; the former are more concerned with the impact of climate change than are the latter. Based on these studies, we propose the following hypothesis for action on climate change:

Hypothesis 1. Liberals are more supportive of actions on climate change than conservatives are.

\subsubsection{Environmental Justice}

Environmental justice pertains to preventing discrimination in environmental benefits or losses, regardless of race, national origin, or income. It is based on the belief that vulnerable communities and groups in terms of economic and political resources, are treated unfairly owing to environmental pollution. According to Ikeme [51], environmental justice is a broad concept that covers all justice issues pertaining to environmental decision-making and that includes both procedural and distributive justice, which usually refers to equity. Climate justice has clear and consistent relationships with the concerns and principles of environmental justice. It pertains to "local impacts and experience, inequitable vulnerabilities, the importance of community voice, and demands for community sovereignty and functioning" [52] (p. 359).

An empirical study conducted by Satterfield et al. [53] showed that individuals perceive more environmental risk when they think that the risk is distributed without injustice at the individual level. Leiserowitz and Akerlof [54] showed that Hispanic and African American individuals and those from "other" races and ethnicities were often the strongest proponents of climate change policies that aimed 
to reduce greenhouse gas emissions. For example, large majorities of all racial and ethnic groups supported regulating carbon dioxide as a pollutant (65-86\%). Kim and Kim [22] showed that perceived environmental justice increases action on climate change.

Hypothesis 2. Belief in environmental justice increases action on climate change.

\subsubsection{Religiosity}

Religious beliefs are fundamental values that influence every aspect of judgement in action. Because Christians believe that nature can be used for people's interests, they have very skeptical views of environmental issues [55]. Sachdeva [56] explained that belief in the sacred aspects of nature is expressed as a sense of denial regarding climate change. This denial appears in different forms, from an outright refusal of the premise of climate change to a divine confirmation of eschatological beliefs.

In an empirical study, Truelove and Joireman [41] reported that the stronger the respondents' adherence to Christian orthodoxy was, the more negative and egoistic behaviors toward climate change they exhibited. Eckberg and Blocker [57] argued that the Christian theology's skepticism about environmental problems stemmed from religious fundamentalism and sectarianism. However, Woodrum and Wolkomir [58] found that when political conservatism was controlled, religiosity had positive effects on the response to the environmental effects of climate change.

However, several studies argued that there are positive relationships between Christian belief and environmentalism. For example, Greenley [59] well demonstrated that Western Christianity has pro-environmental trends. Deane-Drummond [60] defined Christian in terms of its role of solving environmental problems. The basic virtues of Christianity, such as prudence, justice, and temperance, will have a significant impact on solving environmental problems. Peterson [61] regarded Christian theology as a good alternative to solve the ecological crisis and to develop attitudes and behaviors in response to the climate change through the value of Christian environmental ethics. Enderle [62] seeks to solve the basic ethical conflict in the environment through a Christian eco-friendly ethics policy. After Kearns [63] reviewed the religious environmental movement in the United States in the mid-1980s, he found the link between Christian doctrine and environmental theory. Grizzle and Barrett [64] suggested an environmental protection model based on the Christian cosmocentrism approach.

We followed the traditional researches $[55,56]$ in which a sincere belief in religion leads to skepticism regarding climate change and response activities.

Hypothesis 3. The stronger the respondents' religiosity is, the more passive their action on climate change is.

\subsubsection{Personal Norms}

Knez [65] believed that value orientations of egoism or altruism affect pro-environmental behavior because the belief that "we should behave pro-environmentally" is regarded as a moral issue by altruistic individuals but not by egoistic individuals. According to Schwartz's $[66,67]$ norm activation theory, subjective altruistic humanitarian beliefs are closely connected with environmentally friendly behavior. In this theory, moral norms, which have a critical impact on various personal activities, are considered to influence individuals' behavior pertaining to the environment. For example, one of the main causal factors of individuals' environmental responsibility for action is their altruistic moral value, which induces a moral obligation to respond to environmental issues, such as threats to natural objects [27].

Stern [68] reported that when external events adversely affect individual's sense of worth, his or her personal norms activate a powerful response to social action. Moreover, Clayton [69] found that individuals' moral responsibility and accountability for environmental rights play a critical role in fostering his or her active participation in solving the environmental problems of future generations. 
By case studies conducted in Africa, Behrens [70] demonstrated that protecting the environment is consistently related with "moral" importance, status, beliefs, and interrelationships. Smith and Pulver [71] reported that the environmental approach, particularly that based on ethical issues, is more effective in facilitating environmental conservation values and participation in action on climate change. Those with high ethical environmentalism often oppose existing social norms, emphasize community and justice, and are more active in environmental issues. Moreover, personal norms mediate the relationships between environmental values and the willingness to accept climate change policies [29].

Based on this discussion, as altruistic moral obligation has emerged as a personal norm that affects the environmental response to climate change, we propose the following hypothesis:

Hypothesis 4. The higher the respondents' levels of moral norms are, the more active they are against climate change.

\subsubsection{Science and Technology Optimism}

S\&T is a double-edged sword in relation to climate change. Industrial development based on S\&T has led to an increase in environmental problems and rapid climate change. However, it is a tool for solving many environmental problems caused by climate change. According to Arvesen et al. [72], S\&T optimism neglects the interactions of social subsystems and accepts the dominant system structure that disregards climate change. According to Mitchell [73] and Goldberg et al. [74], S\&T optimism is currently prevalent in scientific, political, social, and policy debates on climate change.

S\&T optimism is likely to assist in responding to climate change. It actually triggers the belief that innovation and development will provide solutions for climate change. For example, solar power generation, an eco-friendly energy source, is believed to help solve climate change problems. Although the latest eco-friendly S\&T advancements are not economically viable, such measures have begun to attract public attention because they are regarded as solutions for the problems caused by climate change [73]. Kim and Kim [34] reported that S\&T optimism increases concern about climate change.

Hypothesis 5. The more SET optimism the respondents have, the more active their responses to climate change are.

\subsubsection{Environmentalism}

Environmentalists tend to overcome risk through more active behavior rather than by avoiding the realities of climate change [75]. According to Whitmarsh [22], those with environmental values regard climate change as very dangerous. Thus, environmentalism directly influences individuals' active responses to climate change, whereas it indirectly mediates the relationship between their negative experiences from climate change and the corresponding responses. Carlton and Jacobson [76] showed that environmentalism affects individuals' perceptions of climate change risks. However, its impact may vary depending on the type of perceived risk. Perceptions of greater physical or biological environment risks were significantly related with having more pro-environmental attitudes whereas perceptions of greater economic risks were significantly associated with having more negative environmental attitudes. The environmentalists are interested in preserving natural things, which may elicit an active response to climate change.

Hypothesis 6. Respondents with higher levels of environmentalism have more active responses to climate change. 


\subsection{Perception Factors}

\subsubsection{Perceived Risks}

Risk perception is an important tool for predicting the public's intentions and actual actions on climate change. In the USA, Leiserowitz [21] conducted a risk perception survey on climate change and found that (1) the perception of the risk of climate change was strongly influenced by empirical factors and (2) the higher the individuals' perceived risk was, the more active they were in environmental activities. Further, Steg and Sievers [77] found that the greater the perceived risk to the environment is, the more positive the attitudes and evaluations pertaining to "risk" management strategies and policies are. In a study on the public's environmental risk perception in 119 countries, Lee et al. [78] found that risk perception is one of the powerful variables that induce environmental response activities. Stevenson et al. [79] showed that educating teenagers (who have not yet established their worldviews) regarding risk perception is effective in inducing positive action on climate change. Whitmarsh [22] found that individuals' perceptions of the risks of climate change increase when they have experienced any risks. This increased perception of climate change led to action for it. Of course, even if risk perception does not explain the overall structure of environmental beliefs, it partly explains the related behavioral intentions [80].

Hypothesis 7. The higher the respondents' risk perception is, the more active their response to climate change is.

\subsubsection{Perceived Benefits}

Because lower public support for climate change policy is likely to hinder its effective implementation, this support is essential for bringing about changes to mitigate global warming. Public support depends on the perceived benefits and costs and awareness of climate change and its solutions. Specifically, the perceived benefits of action on climate change are a major driver for policy support [81]. The benefits of solving the climate change problems can motivate individual and global actions. Ecosystem services have potential benefits for human welfare. Biodiversity conservation can provide not only physical and mental benefits but also economic value to humanity [82].

Furthermore, the greater the benefits of reducing the adverse effects of climate change are, the greater the social and psychological benefits are for the public. For example, a better climate increases positive subjective factors, such as health promotion and psychological stability [83]. In an empirical study in which perceived benefits were measured by self-efficacy on a personal level, those benefit reduced the level of concern about climate change [84]. Lubell et al. [85] suggested the global warming activism model $(=[(P G * \mathrm{pi}) * \mathrm{~V}]-\mathrm{C}+\mathrm{B})$, which includes collective efficacy $(\mathrm{PG})$, the probability of success of actions according to personal influence (pi), the common benefit $(\mathrm{V})$, participation costs (C), and benefits from participation (B). Thus, benefits and costs are considered the major factors influencing individuals' environmental actions. Leiserowitz et al. [23] investigated the benefits of global warming mitigation actions through a survey and reported that more than half of the respondents agree that solving the climate change problem leads to benefits such as breaking away from oil dependence, better health, the protection of endangered plants and animals, the creation of green jobs, and the strengthening of the economy.

Hypothesis 8. The greater the respondents' perceived benefits from solving climate change problems are, the more active actions they exhibit.

\subsubsection{Trust}

Trust begins with individuals' beliefs that policy makers, governments, and institutions will protect their interests. Climate change seriously threatens health and life. Levi and Stoker [86] and 
Dalton [87] reported that when trust in institutions is greater, acceptance of government regulations is greater and participation in action programs is more active. This result suggests that trust is an important driver for individuals to take action on climate change.

Paul et al. [88] demonstrated the influence of social capital, a kind of trust, on adaptation to climate change in rural households. Social capital is associated with increased collective cooperation among households with reference to behaviors to adapt to climate change. According to Arbuckle et al. [89], farmers' trust in environmental or agricultural interest groups as sources of climate information is significantly related to their perceived risks regarding climate change as well as support for adaptation and mitigation responses.

However, trust does not explain all actions on climate change. Smith and Mayer [90] examined action on climate change and policy support in 35 nations. They observed a social trap in which lack of trust mitigated the effect of perceived risks on public's willingness to engage in behaviors or to support policies against climate change. Furthermore, they found that this social trap may affect social trust in policy support but not behaviors.

Hypothesis 9. The greater the respondents' trust in actors related to climate change is, the more active their response to it is.

\subsubsection{Negative Emotions}

Hazards associated with negative emotions tend to be perceived as riskier and more dangerous [91]. The emotional aspects of climate change, such as feelings, anger, and sadness, influence the action orientation toward climate change. Among various feelings about climate change, worries are the most common and representative emotion. According to Muis et al. [92], youth in Northern Europe were more likely to respond positively to environmental behavior toward climate change because they were more worried about global warming than other groups were. A strong emotional response to climate change stimulates "interest" in climate change, which results in positive action by recognizing oneself as a subject threatened by climate change [93]. In the US, risk perceptions regarding climate change and policy support for overcoming it were found to be influenced strongly by experiential factors, particularly by affect imagery [13]. However, based on a focus group interview, O'Neill and Nicholson-Cole [94] reported that since alarmist imagery of climate change may succeed in making climate change a concern, it may reduce the readiness to "do something about climate change."

Hypothesis 10. The stronger the respondents' negative feelings regarding climate change are, the more action they take.

\subsubsection{Knowledge}

Knowledge is a major resource for individuals to assess risks and defend themselves from hazards. At the individual level, if the general public or experts lack knowledge, it is difficult for them to evaluate risks and take appropriate actions on climate change. At the community level, barriers to information access and mutual sharing of knowledge on climate change make the implementation of policies less effective [95]. Tabara et al. [96] stressed that knowledge affects the communication, production, and mobilization processes that generate better solutions for climate change. To create transformative solutions for climate change, it is necessary to change not only organizations and networks but also direction of knowledge. In a knowledge production system, the research-policy emphasis needs to move understanding from "what is the problem" to "what is the solution."

In an empirical study that examined local knowledge that was a place-based tool for climate models and geographic sensitivity, Reyes-Garcia et al. [97] reported that rich and detailed knowledge about the impact of climate change on biophysical systems contributed to the creation of a better 
understanding of climate change at the local level. Stoutenborough and Vedlitz [24] found that different types of knowledge play different roles in evaluating the risks of climate change. For instance, perceived knowledge tends to lead to less concern about climate change than assessed knowledge does. Perceived knowledge is subjective perceptions of one's knowledge whereas assessed knowledge is objective assessment of one's knowledge. Subjective knowledge measured the degree to which individuals felt how much information they had (e.g., How informed do you consider yourself to be on the following issues?). Objective knowledge, on the other hand, was measured by the number of correct answers about fact (e.g., Nitrous oxide is a greenhouse gas). Since the assessed knowledge can exactly measure the knowledge, it concerns with the risk perception of climate change.

Bord et al. [98] found that causal knowledge related to global warming is related to belief in and intention to act on climate change. According to O'Connor et al. [80], knowledge plays a role in explaining behavioral intentions regarding climate change. Specifically, the greater the knowledge is, the greater the voluntary action to respond to climate change is. Similarly, Kim and Kim [34] reported that knowledge increases climate change adaption behavior.

However, Liu et al. [99] found that the level of knowledge was not strongly related to teachers' attitudes and beliefs about global climate change. Specifically, teachers who were very concerned about climate issues had misconceptions about them.

Hypothesis 11. The more knowledge on climate change that respondents have, the stronger their actions on climate change are.

\section{Sample and Measures}

To get the data, a web survey was conducted in South Korea. The questionnaire aimed to measure the attitudes and behaviors related to climate change. Survey data was collected in May 2017 from respondents selected through random sampling that considered gender, age, and region as criteria for quota. We distributed 12,977 e-mails to individuals from the survey pool; 1873 opened their e-mail, and 714 completed the survey. In the final sample, $49.6 \%$ of the respondents were men, $50.4 \%$ were women, $35.2 \%$ were younger than 40 years, $40.6 \%$ were aged between 40 and 59 years, and $24.3 \%$ were aged over 60 years. In terms of education level, $51.0 \%$ of the respondents had a high school degree or lower, and $49.0 \%$ had a university-level degree.

Except for action on climate change and ideology, theoretical concepts were generally measured by using a five-point Likert scale ranging from one point (strongly disagree) to five points (strongly agree). Table 2 presents the theoretical concepts, the items measuring them, and reliability of the scale. All reliability values (Cronbach's alpha) were above the recommended critical point $(0.60)$. To measure action on climate change, we asked the question "To what extent are you engaging in the following activities to solve the climate change problem? Please choose between 1 point (never act) and 7 points (always act)." Target actions included the following: (1) recycling, (2) energy saving during heating, and (3) buying energy-efficient electronics. The reliability of this scale was 0.793 . Ideology was measured with a ten-point scale ranging from 1 (liberal) to 10 (conservative). 
Table 2. Concepts, items measuring the concepts, and the reliability of the scale.

\begin{tabular}{|c|c|c|}
\hline Concept & Items Measuring the Concept & Reliability \\
\hline Environmental justice & $\begin{array}{l}\text {-Climate change problems only have negative effects on the poor. } \\
\text {-Climate change affects less developed countries more as compared to } \\
\text { developed countries. } \\
\text {-Climate change damages poor people like me. } \\
\text {-Climate change only afflicts people who are in a socially } \\
\text { disadvantaged position. }\end{array}$ & 0.890 \\
\hline Religiosity & $\begin{array}{l}\text {-I am religious. } \\
\text {-I am convinced of the existence of God. }\end{array}$ & 0.877 \\
\hline Personal norms & $\begin{array}{l}\text {-I feel a moral sense of duty to solve the climate change problem. } \\
\text {-For future generations, I feel a sense of responsibility to address } \\
\text { climate change issues. }\end{array}$ & 0.911 \\
\hline $\begin{array}{l}\text { science and technology } \\
\text { (S\&T) optimism }\end{array}$ & $\begin{array}{l}\text {-Science and technology make our lives healthier and more } \\
\text { convenient. } \\
\text {-Science and technology solve more problems than they create. } \\
\text {-Science and technology perform more positive functions than } \\
\text { negative ones }\end{array}$ & 0.793 \\
\hline Environmentalism & $\begin{array}{l}\text {-Currently, the earth faces a serious environmental and } \\
\text { ecological crisis. } \\
\text {-The Earth has already surpassed its limitations. } \\
\text {-Animals and plants have as much of a right to live as do } \\
\text { human beings. } \\
\text {-Since nature is very sensitive, it could be destroyed easily. }\end{array}$ & 0.921 \\
\hline Perceived risks & $\begin{array}{l}\text {-Climate change is a serious threat to the survival of humankind. } \\
\text {-Planetary changes due to global warming will cause me a lot } \\
\text { of damage. } \\
\text {-I am worried that the problems caused by global warming will be } \\
\text { harmful for humans. }\end{array}$ & 0.793 \\
\hline Perceived benefits & $\begin{array}{l}\text {-Resolving climate change problems would have tremendous benefits. } \\
\text { Solving climate change problems will lead to economic development. }\end{array}$ & 0.839 \\
\hline Trust & $\begin{array}{l}\text {-How much do you trust the following organizations in addressing } \\
\text { climate change and energy issues? } 1 \text {. University research institutes, } 2 \text {. } \\
\text { Environmental protection organizations, } 3 \text {. Consumer organizations, } \\
\text { 4. Press, } 5 \text {. Government, } 6 \text {. Private companies, } 7 \text {. Energy companies, } \\
\text { 8. Scientists }\end{array}$ & 0.817 \\
\hline Negative emotions & $\begin{array}{l}\text {-I am sad to see the climate change occurring due to global warming. } \\
\text {-I am worried about the climate change occurring due to global } \\
\text { warming. } \\
\text {-I am afraid of the climate change occurring due to global warming. }\end{array}$ & 0.912 \\
\hline Knowledge & $\begin{array}{l}\text {-I know the problems of climate change well. } \\
\text {-I am more knowledgeable about climate change than are others. }\end{array}$ & 0.839 \\
\hline
\end{tabular}

\section{Analysis and Findings}

\subsection{Basic Structure}

To understand the basic relationships between the variables, we calculated the mean values on climate change according to sociodemographic variables, such as gender, age, education, income, and social class. Figure 1 presents the results. 


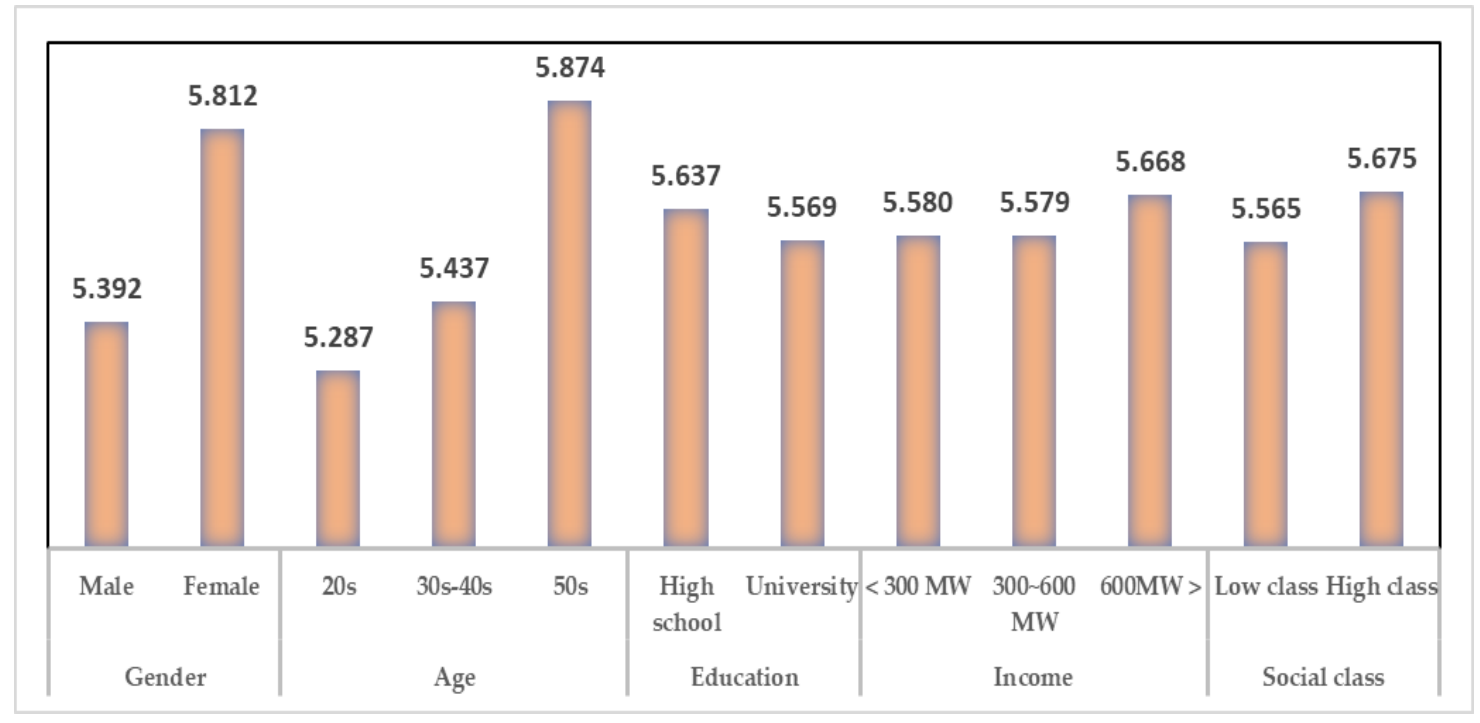

Figure 1. Mean values on climate change across sociodemographic groups.

Women were more willing to act on climate change than men were. According to Bord and O'Connor [100], O'Connor, et al. [80], and McCright [101], women recognize greater risks of climate change than men do. Thus, the former exhibits more voluntary actions on climate change than the latter does.

As age increases, actions on climate change increase. Reinhart [102] reported an age gap in actions related to global warming. Specifically, he found that, in the US, younger individuals worried about climate change more than older individuals did. Furthermore, $70 \%$ of those aged 18 to 34 years worried about global warming as compared to $62 \%$ of those aged 35 to 54 years and $56 \%$ of those aged 55 years or older. However, our data showed that older individuals exhibited more action on climate change as compared to younger individuals. This finding demonstrates differences in the consciousness of and action on climate change in South Korea. Although young individuals worry about climate change, they do not necessarily engage in related actions. In contrast, although older individuals are less concerned about climate change, they more actively engage in the relevant behavior.

To check the significance of difference between groups, we executed the Anova-test. As seen on Table 3, education, income and social classes did not show to be statically significant.

Table 3. Anova-test.

\begin{tabular}{cccccc}
\hline & Gender & Age & Education & Income & Social Class \\
\hline F-value & 31.469 & 22.544 & 0.556 & 0.546 & 1.925 \\
\hline P-value & 0.000 & 0.000 & 0.579 & 0.579 & 0.166 \\
\hline
\end{tabular}

However, in terms of education, Hamilton [103] argued that the level of education interacts with orientation to government policies on climate change. Education increases knowledge about the causes and consequences of climate change, leading to action to mitigate it. According to McCright and Dunlap [33], income has a positive influence on the belief that anthropogenic climate change is occurring. According to the need hierarchy, the rich pursue a higher level of desire because their lower-level economic needs are satisfied. Thus, action on climate change is a means of meeting their high-level needs and, thus, wealthier individuals exhibit more action on climate change. Finally, in terms of social class, according to Tranter [104] and Gifford and Nilsson [105], consciousness of social class evidently appears in political or social interests. Thus, environmental interests and perceptions were affected mainly by individuals' social factors. 
To examine the simple relationship between variables, we performed simple and partial correlation analyses by controlling for age, income, sex, education, and social class. In Table 4, the portion below the diagonal presents the simple correlation results, and the portion above the diagonal presents the partial correlation results. Among the simple correlations, action on climate change was positively correlated with environmental justice, personal norm, S\&T optimism, perceived risk, negative emotion, knowledge, trust, and environmentalism. In terms of the sizes of the correlation coefficients, among the value factors, action on climate change showed the highest correlation with personal norm, followed by environmentalism, S\&T optimism, and environmental justice. Although ideology and religiosity did not have significant relationships with action on climate change, they showed significant partial correlations. This result implies that sociodemographic factors suppress the effect of the relationships between ideology/religiosity and action on climate change such that the conservative ideology and a religious belief decrease action on climate change.

Among the perception factors, action showed the highest correlation with perceived risks, followed by negative emotions, perceived benefits, knowledge, and trust. This finding was consistent with those of a previous study by Steg and Sievers [77], who found that greater risk perception was strongly associated with environmental behavior. Compared to the coefficients observed on the value factors, perceived risks and negative emotions were more strongly correlated with action on climate change. This finding implies that more immediate perceptions, rather than fundamental values, critically affect climate change-related behavior. 
Table 4. Simple and partial correlations among value and perception factors.

\begin{tabular}{|c|c|c|c|c|c|c|c|c|c|c|c|c|c|}
\hline & & 1 & 2 & 3 & 4 & 5 & 6 & 7 & 8 & 9 & 10 & 11 & 12 \\
\hline \multicolumn{2}{|c|}{ 1. Action on climate change } & 1 & $-0.068^{*}$ & $0.124^{* * *}$ & -0.041 & $0.355^{* * *}$ & $0.187^{* * *}$ & $0.331^{* * *}$ & $0.416^{* * *}$ & $0.375^{* *}$ & $0.118^{* * *}$ & $0.398^{* * *}$ & $0.212^{* * *}$ \\
\hline \multirow[b]{2}{*}{ Value factors } & 2. Ideology (conservative) & 0.004 & 1 & $-0.117^{* * *}$ & $0.122 * * *$ & $-0.123^{* * *}$ & 0.003 & $\underset{* * *}{-0.131}$ & $-0.120 *$ & $-0.103^{* * *}$ & -0.015 & $-0.155^{* * *}$ & $-0.142 * * *$ \\
\hline & $\begin{array}{l}\text { 3. Environmental justice } \\
\text { 4. Religiosity } \\
\text { 5. Personal norms } \\
\text { 6. S\&T optimism } \\
\text { 7. Environmentalism }\end{array}$ & $\begin{array}{l}0.108^{* * *} \\
0.059^{* * *} \\
0.391^{* *} \\
0.188^{* * *} \\
0.319^{* * *} \\
\end{array}$ & $\begin{array}{c}-0.114^{* * *} \\
0.164^{* * *} \\
-0.076^{* *} \\
0.020 \\
-0.122^{* * *} \\
\end{array}$ & $\begin{array}{c}1 \\
0.069^{*} \\
0.110^{* * *} \\
0.060 \\
0.144^{* * *} \\
\end{array}$ & $\begin{array}{c}0.069^{*} \\
1 \\
0.106^{* * *} \\
0.062^{*} \\
-0.029 \\
\end{array}$ & $\begin{array}{c}0.133^{* * *} \\
0.056 \\
1 \\
0.117^{* * * *} \\
0.316^{* * * *} \\
\end{array}$ & $\begin{array}{c}0.063^{*} \\
0.048 \\
0.098^{* * *} \\
1 \\
0.062 \\
\end{array}$ & $\begin{array}{c}0.140 * * * \\
-0.038 \\
0.329^{* * *} \\
0.070 * \\
1 \\
\end{array}$ & $\begin{array}{l}0.212^{* * *} \\
0.057 \\
0.550^{* * *} \\
0.071^{*} \\
0.499^{*} \\
\end{array}$ & $\begin{array}{l}0.195^{* * *} \\
0.074^{* *} \\
0.522^{* * *} \\
0.138^{* * *} \\
0.354^{* * *}\end{array}$ & $\begin{array}{l}-0.055 \\
0.158^{* * *} \\
0.120^{* * *} \\
0.255^{* * *} \\
-0.022 \\
\end{array}$ & $\begin{array}{c}0.202^{* * *} \\
0.010 \\
0.640^{* *} \\
0.079^{* *} \\
0.455^{* * *}\end{array}$ & $\begin{array}{l}0.181^{* * *} \\
0.052^{* * *} \\
0.313^{* * *} \\
0.123^{* * *} \\
0.157^{* * *}\end{array}$ \\
\hline $\begin{array}{l}\text { Perception } \\
\text { factors }\end{array}$ & $\begin{array}{l}\text { 8. Perceived risks } \\
\text { 9. Perceived benefits } \\
\text { 10. Trust } \\
\text { 11. Negative emotions } \\
\text { 12. Knowledge }\end{array}$ & $\begin{array}{l}0.426^{* * *} \\
0.382^{* * *} \\
0.188^{* * *} \\
0.424^{* * *} \\
0.222^{* * *}\end{array}$ & $\begin{array}{l}-0.085^{* *} \\
-0.078^{* *} \\
0.038^{* * *} \\
-0.124^{* * *} \\
-0.121^{* * *}\end{array}$ & $\begin{array}{l}0.204^{* * *} \\
0.187^{* * *} \\
-0.064^{*} \\
0.192^{* * *} \\
0.143^{* * *}\end{array}$ & $\begin{array}{c}0.083^{* *} \\
0.096^{* *} \\
0.209^{* * *} \\
0.056 \\
0.077^{* *}\end{array}$ & $\begin{array}{l}0.555^{* * *} \\
0.528^{* * *} \\
0.167^{* * *} \\
0.647^{* * *} \\
0.349^{* * *}\end{array}$ & $\begin{array}{l}0.078^{* * *} \\
0.146^{* * *} \\
0.262^{* * *} \\
0.082^{* *} \\
0.147^{* * *}\end{array}$ & $\begin{array}{l}0.498^{* * *} \\
0.350^{* * *} \\
-0.021 \\
0.455^{* * *} \\
0.128^{* * *}\end{array}$ & $\begin{array}{c}1 \\
0.544^{* * *} \\
0.016 \\
0.735^{* * *} \\
0.218^{* * *}\end{array}$ & $\begin{array}{l}0.539^{* * *} \\
1 \\
0.128^{* * *} \\
0.587^{* * *} \\
0.269^{* * *}\end{array}$ & $\begin{array}{c}-0.015 \\
0.107^{* * *} \\
1 \\
0.080^{* *} \\
0.120^{* * *}\end{array}$ & $\begin{array}{c}0.735^{* * *} \\
0.585^{* * * *} \\
0.047 \\
1 \\
0.286^{* * *}\end{array}$ & $\begin{array}{c}0.221^{* * *} \\
0.263^{* * *} \\
0.090^{* *} \\
0.283^{* * *} \\
1\end{array}$ \\
\hline
\end{tabular}




\subsection{Determinant Structure}

To understand the causal relationships between the variables, we regressed action on climate change on the sociodemographic, value, and perception factors. The results are presented in Table 5.

Table 5. Multiple regression analysis for action on climate change.

\begin{tabular}{|c|c|c|c|c|c|c|}
\hline & & B & SE & Beta & $\mathbf{t}$ & Sig. \\
\hline \multirow{6}{*}{$\begin{array}{c}\text { F1: } \\
\text { Sociodemographic } \\
\text { factors }\end{array}$} & Constant & 0.401 & 0.349 & & 1.152 & 0.250 \\
\hline & Gender (female) & $0.385^{* * *}$ & 0.064 & 0.191 & 5.988 & 0.000 \\
\hline & Age & $0.014^{* * *}$ & 0.003 & 0.191 & 5.416 & 0.000 \\
\hline & Education level & 0.072 & 0.071 & 0.036 & 1.020 & 0.308 \\
\hline & Income & $-0.206^{* *}$ & 0.084 & -0.092 & -2.458 & 0.014 \\
\hline & Social class & $0.063 * *$ & 0.025 & 0.097 & 2.488 & 0.013 \\
\hline \multirow{6}{*}{ F2: Value factors } & Ideology (conservative) & 0.013 & 0.018 & 0.023 & 0.707 & 0.480 \\
\hline & Environmental justice & 0.019 & 0.040 & 0.015 & 0.475 & 0.635 \\
\hline & Religiosity & $-0.072^{* * *}$ & 0.028 & -0.084 & -2.554 & 0.011 \\
\hline & Personal norms & $0.099^{* * *}$ & 0.056 & 0.077 & 1.765 & 0.078 \\
\hline & S\&T optimism & $0.152^{* * *}$ & 0.047 & 0.105 & 3.264 & 0.004 \\
\hline & Environmentalism & $0.182 * * *$ & 0.056 & 0.118 & 3.273 & 0.001 \\
\hline \multirow{5}{*}{$\begin{array}{l}\text { F3: Perception } \\
\text { factors }\end{array}$} & Perceived risks & $0.247^{* * *}$ & 0.067 & 0.181 & 3.711 & 0.000 \\
\hline & Perceived benefits & $0.164^{* * *}$ & 0.056 & 0.117 & 2.908 & 0.004 \\
\hline & Trust & $0.131 *$ & 0.057 & 0.077 & 2.290 & 0.022 \\
\hline & Negative emotions & 0.062 & 0.071 & 0.046 & 0.871 & 0.384 \\
\hline & Knowledge & $0.091 *$ & 0.050 & 0.063 & 1.809 & 0.071 \\
\hline \multirow{2}{*}{\multicolumn{2}{|c|}{$\begin{array}{c}\text { F-value } \\
\mathrm{R}^{2} / \text { Adjusted } \mathrm{R}^{2}\end{array}$}} & \multirow{2}{*}{\multicolumn{5}{|c|}{$\begin{array}{c}23.497 * * * \\
0.350 / 0.335\end{array}$}} \\
\hline & & & & & & \\
\hline \multirow{3}{*}{\multicolumn{2}{|c|}{$\begin{array}{l}\text { F1: } R^{2} / \text { Adjusted } R^{2} \\
\text { F2: } R^{2} / \text { Adjusted } R^{2} \\
\text { F3: } R^{2} / \text { Adjusted } R^{2}\end{array}$}} & \multicolumn{5}{|c|}{$0.120 / 0.113$} \\
\hline & & \multicolumn{5}{|c|}{$0.219 / 0.212$} \\
\hline & & \multicolumn{5}{|c|}{$0.254 / 0.249$} \\
\hline
\end{tabular}

Among the sociodemographic factors, gender, age, income, and social class influenced climate change-response behavior. Specifically, women showed a more active response to climate change than men did. This finding confirms those of $\mathrm{O}^{\prime}$ Connor et al. [80] that women are more involved in action on climate change than men are.

Age positively affected environmental behavior. In the present study, older individuals exhibit more active response to climate change than younger ones. This finding was unexpected because previous findings demonstrated that young individuals were more likely to respond positively to environmental behavior, as they were more worried about climate change [92]. The present finding may be attributed to the fact that older individuals may have more resources than younger individuals. If climate change threatens their resource, the older will try to protect it by doing some actions against climate change.

Income and social class had contrasting effects for action on climate change. As income increased, the response to climate change decreased, but as social class becomes higher, the response to climate change became more active. These results suggest that the objective and subjective determinants of action differ in that income is an objective indicator, whereas social class is a subjective one. Based on the standardized beta coefficients, among the five demographic variables, sex and age were the most significant predictors of action on climate change. Because two variables are attributes that cannot be changed artificially, they could contribute to the crystallization of behavior on climate change.

Among the five value factors, conservative ideology does not affect action on climate change. This result is contrary to those reported by McCright and Dunlap [33] and Borick and Rabe [50], who confirmed that liberalism was associated with more worry about and action on climate change. Next, religiosity negatively influenced action on climate change. According to Truelove 
and Joireman [29], the stronger the adherence to Christian orthodoxy is, the more negative and egoistic the orientation toward action on climate change is. These findings confirm the passive role of religious beliefs in climate change. Personal norms have a positive impact on action against climate change. This finding confirms the results of Jansson and Dorrepaal [30] that moral foundations related to harm and fairness, have positively impact personal action on climate change. Further, this study found that S\&T optimism has a positive impact on action against climate change. Among the five value variables, S\&T optimism has the greatest explanatory power. Individuals tend to support the development of S\&T because it leads to economic development [73]. The functional contribution of S\&T can be applied to issues of climate change. Environmental science based on ecology is the main instrument to develop solutions for climate change problems. Next, the present findings revealed that greater environmentalism is related to active response to climate change. According to Bain et al. [75], environmentalists tend to overcome risks through doing active behavior rather than avoiding the realities of climate change. Lastly, environmental justice does not have a significant impact on action against climate change.

Four out of the five perception factors positively impact action on climate change. First, we confirm the hypothesis that greater risk perception is associated with a more active response to climate change. Similarly, the greater the perceived benefits from solving climate change problems are, the greater the positive action on climate change is. Solving climate change problems could lead to benefits, such as good health and psychological stability [83]. Next, the higher the level of trust is, the more likely the respondents are to increase their active responses to climate change. Torgler [106] reported that greater trust in institutions is associated with more acceptance of government regulations and more active adherence to government-defined action guidelines. Further, knowledge has a positive impact for action on climate change. Finally, this study found no significant effect of negative affect on the response to climate change.

Based on unstandardized coefficients, gender and age explain the largest proportion of variance in action on climate change, followed by perceived risks, perceived benefits, environmentalism, and S\&T optimism. These findings imply that action on climate change can be induced by a mix of structural, perceptual, and value factors. However, because age and gender cannot be changed by interventions in practice, the perception and value factors play a significant role in solving climate change problems. The variance explained by each of these three factors confirms the critical role of values and perceptions. The last three rows in Table 5 present the R-square/adjusted R-square when each of these three factors constitutes a separated model. The demographic, value, and perception factors explain $12 \%, 21.9 \%$, and $25.4 \%$ of the variance in action on climate change, respectively. Evidently, among the three factors, the perception factor explains the largest proportion of variance.

\subsection{Interaction Structure}

The regression analysis showed the direct impact of values for action on climate change. Therefore, to further explore how these value factors moderate the relationship between perceptions and action on climate change, we applied the procedure of moderation analysis, suggested by Baron and Kenny [107]. First, we created interaction terms in which each of the five perception variables was multiplied with each of the six value variables. Subsequently, among the 30 interaction terms obtained, four moderating terms appeared significant. For those four interactions, we executed a simple slope test. Figures $2-5$ show the moderating effect of values on the relationship between perceptions and action on climate change. In these figures, the $X$-axis represents the independent risk perception variables, and the $Y$-axis represents action on climate change. IV represents the independent variables, and MV is the moderating variable.

As evident from Figure 2, perceived risks increase action on climate change. This impact depends on S\&T optimism. Specifically, high rather than low S\&T optimism facilitates this relationship. Furthermore, this moderating effect of S\&T optimism appears more clearly when perceived risks are 
low as compared to when they are high. As perceived risks increase, the moderating effect of S\&T optimism becomes weaker.

The impact of perceived benefits for action on climate change is also moderated by S\&T optimism (Figure 3). Perceived benefits promote action on climate change. This effect is stronger when S\&T optimism is high than when it is low. Further, the moderating effect of S\&T optimism becomes weaker as perceived benefits increase.

Figure 4 shows that perceived benefits increase action on climate change. However, this impact is moderated by environmentalism. Specifically, environmentalism facilitates the impact of perceived benefits for action on climate change. However, this facilitating effect decreases with an increase in perceived benefits.

Figure 5 shows that S\&T optimism has a moderating effect on the relationship between negative emotions and action on climate change. Specifically, when S\&T optimism was high, action on climate change decreased with an increase in negative emotions. However, when S\&T optimism was low, negative emotions increased the response to climate change. This moderating effect of S\&T optimism is a notable result in that it confirms the findings of the regression analysis in which S\&T optimism has a positive impact on action against climate change.

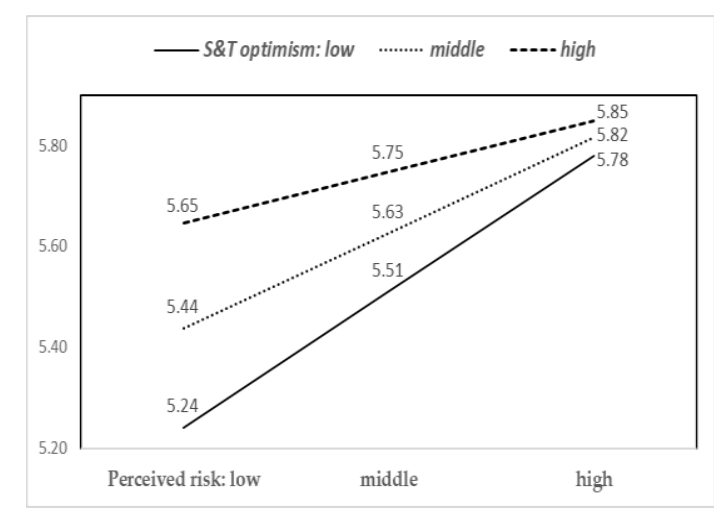

Figure 2. IV (independent variables): Perceived risk $\times$ MV (moderating variable): S\&T optimism.

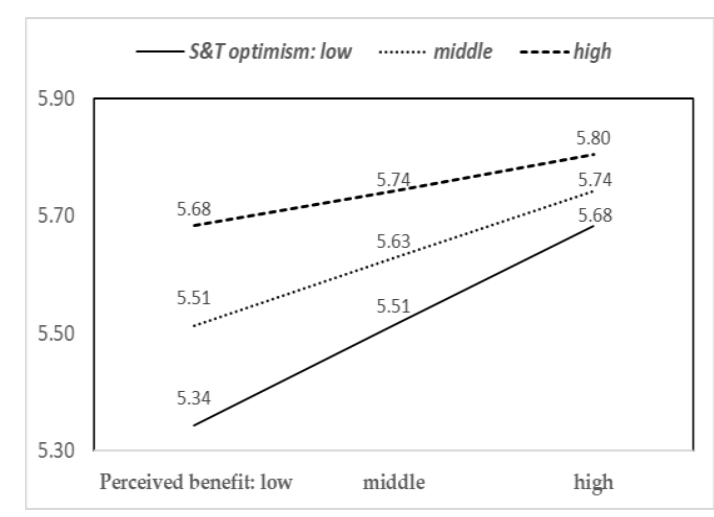

Figure 3. IV: Perceived benefit $\times$ MV: S\&T optimism. 


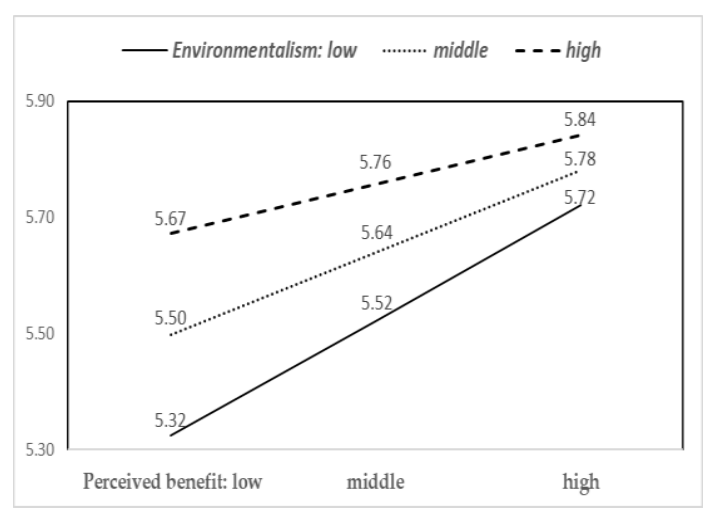

Figure 4. IV: Perceived benefit $\times$ MV: Environmentalism

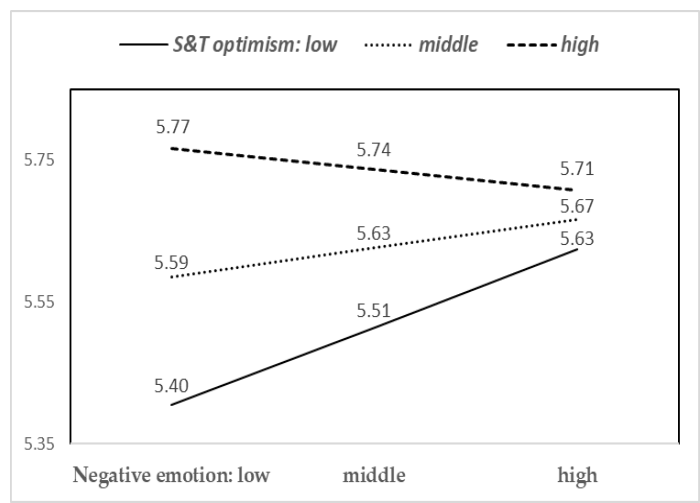

Figure 5. IV: Negative emotion $\times$ MV: S\&T optimism.

\section{Summary and Implications}

As the problem of climate change becomes more serious, the importance of response actions to solve this problem is increasing. The present study focused on the role of value variables in facilitating or mitigating the response to climate change. Fundamental values systematically influence individuals' attitudes and behaviors. Our study examined the impact of value factors on action against climate change and compared their explanatory power with that of perception factors. Among various values, we focused on six variables: ideology, environmental justice, religiosity, personal norms, S\&T optimism, and environmentalism. Moreover, we examined how these value factors moderate the relationships between the perception variables and action on climate change. The major findings of this study are following.

First, women and older respondents exhibit more active action on climate change than do men and younger respondents, respectively. This finding of women's active behavior towards climate change is consistent with that observed in previous research $[80,101]$. The age-related finding observed in the present study is unusual considering that previous studies reported that young individuals were more aware of climate change than older individuals were [92]. Finally, the regression analysis revealed that more income decreases action on climate change, whereas higher social class increases it.

Second, the regression analysis showed that, among the value factors, conservative religiosity reduces action on climate change, whereas personal norms, S\&T optimism, and environmentalism increase it. Among the perception factors, perceived risks, perceived benefits, trust, and knowledge have positive impacts on the response to climate change. In addition, female gender and older age have greater explanatory power for action on climate change, followed by environmentalism, perceived risks, and perceived benefits. Among the three factors, the perception factor explains a greater proportion of action on climate change as compared to the sociodemographic and value factors. 
Third, S\&T optimism moderates the impacts of perceived benefits, perceived risks, and negative emotions on action against climate change. Perceived risk has a positive impact on individuals' action on climate change, and this effect is further enhanced when S\&T optimism is high. Perceived benefits increase action on climate change, which is facilitated by high S\&T optimism and high environmentalism. However, these moderating effects tended to weaken when the perceived risks or benefits increase. Moreover, environmentalism moderates the relationship between perceived benefits and action on climate change. The impact of negative emotions for action on climate change entirely depends on S\&T optimism. Specifically, when S\&T optimism is high, negative emotions decrease action on climate change, but when S\&T optimism is low, negative emotions reinforce action on climate change.

Together, the results of this study show that values have significant direct and indirect impacts for action on climate change. Perception variables also affect action on climate change, but their effect is moderated by value factors. These results have the following implications.

First, considering that the level of perceived risks and benefits has a significant impact on action against climate change, authorities need to develop a communication strategy that emphasizes the risks of climate change and demonstrates the benefits of engaging in behaviors that address the climate change problems. Moreover, it is necessary to increase the credibility of individuals who engage in climate change-related activities and to improve civic education for increasing knowledge related to climate change. According to Huh et al. [108], since people have finite cognitive resources in dealing with news, they do not consider lot of things at once. Therefore, in the case of making the communication for risk for climate change, it needs to transmit the simplified messages for receivers.

Second, with reference to values, we found that religiosity, personal norms, S\&T optimism, and environmentalism affect action on climate change. However, it is difficult to change values within a short time because they are structured and crystalized over the course of a long socialization process. Therefore, value changes require long-term strategies and demand strong stimulation to question the fundamental beliefs of individuals. Of course, it is unlikely that an individual will personally experience earthquakes, tsunamis, and droughts that occur due to climate change, but it is possible to indirectly experience them by participating in disaster response training programs, disaster experience facilities, and acquiring related information through the media.

The present study has the following limitations. First, we focused only on six values among many value sets. Since there are various values and cultures $[109,110]$, we need to verify the role of various values in the future. Second, although we focused only on perception factors and value factors, we did not examine the contextual or communication dimensions [111-115] or relationships between various perceptions $[116,117]$. Third, future studies need to verify the overall causal model, not the effects of individual variables and elements. Fourth, one of the limitations of this study is that among various actions against climate change, few actions were selected. Future research should include diet (avoiding animal agriculture) and transportation choices in measuring the response on climate change.

Author Contributions: S.-A.K. performed the formal analysis, wrote the original draft of the manuscript, and developed the visual representations of the data; S.K. worked on writing the review and editing the final manuscript; J.E.L. conceptualized the study, methodology, and process of data validation. Three authors contributed equally to this work.

Funding: This work was supported by the Ministry of Education of the Republic of Korea and the National Research Foundation of Korea (NRF-2017S1A5B8059946). This research was funded by the National Research Foundation of Korea Grant funded by the Korean Government.

Conflicts of Interest: The authors declare no conflicts of interest. 


\section{References}

1. IPCC (Intergovernmental Panel on Climate Change). Summary for Policymakers. In Climate Change 2014: Mitigation of Climate Change. Contribution of Working Group III to the Fifth Assessment Report of the Intergovernmental Panel on Climate Change; Edenhofer, O., Pichs-Madruga, R., Sokona, Y., Farahani, E., Kadner, S., Seyboth, K., Adler, A., Baum, I., Brunner, S., Eickemeier, P., et al., Eds.; Cambridge University Press: Cambridge, UK; New York, NY, USA, 2014.

2. Adger, W.N. Social capital, collective action, and adaptation to climate change. Econ Geogr. 2003, 79, 387-404. [CrossRef]

3. OECD. Climate Change Mitigation: Policies and Progress; OECD Publishing: Paris, France, 2015.

4. Ampaire, E.L.; Jassogne, L.; Providence, H.; Acosta, M.; Twyman, J.; Winowiecki, L.; van Asten, P. Institutional challenges to climate change adaptation: A case study on policy action gaps in Uganda. Environ. Sci. Policy. 2017, 75, 81-90. [CrossRef]

5. Damsø, T.; Kjær, T.; Christensen, T.B. Local climate action plans in climate change mitigation-examining the case of Denmark. Energy Policy 2016, 89, 74-83. [CrossRef]

6. Klinsky, S.; Roberts, T.; Huq, S.; Okereke, C.; Newell, P.; Dauvergne, P.; Keck, M. Why equity is fundamental in climate change policy research. Glob. Environ. Chang. 2017, 44, 170-173. [CrossRef]

7. Marshall, N.A.; Park, S.; Howden, S.M.; Dowd, A.B.; Jakku, E.S. Climate change awareness is associated with enhanced adaptive capacity. Agric. Syst. 2013, 117, 30-34. [CrossRef]

8. Adebayo, A.A.; Onu, J.I.; Adebayo, E.F. Farmers' Awareness, vulnerability and adaptation to climate change in Adamawa state, Nigeria. Br. J. Arts Soc. Sci. 2012, 9, 104-115.

9. Lorenzoni, I.; Nicholson-Cole, S.; Whitmarsh, L. Barriers perceived to engaging with climate change among the UK public and their policy implications. Glob. Environ. Chang. 2007, 17, 445-459. [CrossRef]

10. Schultz, P.W.; Oskamp, S. Effort as a moderator of the attitude-behavior relationship: General environmental concern and recycling. Soc. Psychol. Q. 1996, 59, 375-383. [CrossRef]

11. Skalík, J. Climate Change awareness and attitudes among adolescents in the Czech Republic. Envigogika 2015, 10. [CrossRef]

12. Mase, A.S.; Gramig, B.M.; Prokopy, L.S. Climate change beliefs, risk perceptions, and ptation behavior among Midwestern US crop farmers. Clim. Risk Manag. 2017, 15, 8-17. [CrossRef]

13. Nordlund, A.M.; Garvill, J. Effects of values, problem awareness, and personal norm on willingness to reduce personal car use. J. Environ. Psychol. 2003, 23, 339-347. [CrossRef]

14. Spence, A.; Poortinga, W.; Butler, C.; Pidgeon, N.F. Perceptions of climate change and willingness to save energy related to flood experience. Nat. Clim. Chang. 2011, 1, 46. [CrossRef]

15. Groulx, M.; Brisbois, M.C.; Lemieux, C.J.; Winegardner, A.; Fishback, L. A role for nature-based citizen science in promoting individual and collective climate change action? a systematic review of learning outcomes. Sci. Commun. 2017, 39, 45-76. [CrossRef]

16. Spence, A.; Poortinga, W.; Pidgeon, N. The psychological distance of climate change. Risk Anal. 2012, 32, 957-972. [CrossRef]

17. Visschers, V.; Siegrist, M. Differences in risk perception between hazards and between individuals. In Psychological Perspectives on Risk and Risk Analysis: Theory, Models, and Applications; Raue, M., Lermer, E., Streicher, B., Eds.; Springer International Publishing AG: Basel, Switzerland, 2018; pp. 63-80.

18. Frondel, M.; Simora, M.; Sommer, S. Risk perception of climate change: Empirical evidence for Germany. Ecol. Econ. 2017, 137, 173-183. [CrossRef]

19. O'Brien, K.L.; Wolf, J. A values-based approach to vulnerability and adaptation to climate change. WIREs Clim. Chang. 2010, 1, 232-242. [CrossRef]

20. Costa-Font, J.; Mossialos, E. 'Ambivalent' individual preferences towards biotechnology in the European Union: Products or processes? J. Risk Res. 2005, 8, 341-354. [CrossRef]

21. Leiserowitz, A. Climate change risk perception and policy preferences: The role of affect, imagery, and values. Clim. Chang. 2006, 77, 45-72. [CrossRef]

22. Whitmarsh, L. Are flood victims more concerned about climate change than other people? the role of direct experience in risk perception and behavioural response. J. Risk Res. 2008, 11, 351-374. [CrossRef] 
23. Leiserowitz, A.; Maibach, E.; Roser-Renouf, C.; Feinberg, G.; Howe, P. Public Support for Climate and Energy Policies in September, 2012; Yale Project On Climate Change Communication; Yale University and George Mason University: New Haven, CT, USA, 2012; Available online: Http:/ /Environment.Yale.Edu/Climate/ Publications/Policy-Support-September-2012/ (accessed on 1 May 2018).

24. Stoutenborough, J.W.; Vedlitz, A. The effect of perceived and assessed knowledge of climate change on public policy concerns: An empirical comparison. Environ. Sci. Policy. 2014, 37, 23-33. [CrossRef]

25. Whitmarsh, L. Scepticism and uncertainty about climate change: Dimensions, determinants and change over time. Glob. Environ. Chang. 2011, 21, 690-700. [CrossRef]

26. Wolf, J.; Allice, I.; Bell, T. Values, climate change, and implications for adaptation: Evidence from two communities in Labrador, Canada. Glob. Environ. Chang. 2013, 23, 548-562. [CrossRef]

27. Stern, P.C.; Dietz, T.; Abel, T.; Guagnano, G.A.; Kalof, L. A value-belief-norm theory of support for social movements: The case of environmentalism. Hum. Ecol. Rev. 1999, 6, 81-97.

28. Rhead, R.; Elliot, M.; Upham, P. The Structure of British Attitudes towards Climate Change: A Re-Evaluation of the VBN Model. The Cathie Marsh Centre for Census and Survey Research. 2014. Available online: http:/ / hummedia.manchester.ac.uk/institutes/cmist/archive-publications/working-papers/2014/ 2014-06-Structure_and_Dimensions_of_EC-FINAL.pdf (accessed on 2 February 2019).

29. Nilsson, A.; Borgstede, C.; Biel, A. Willingness to accept climate change strategies: The effect of values and norms. J. Environ. Psychol. 2004, 24, 267-277. [CrossRef]

30. Jansson, J.; Dorrepaal, E. Personal norms for dealing with climate change: Results from a survey using moral foundations theory. Sustain. Dev. 2015, 23. [CrossRef]

31. Milton, K. Introduction: Environmentalism and anthropology. In Environmentalism; Taylor \& Francis Group: London, UK, 2003; pp. 11-26.

32. Hamilton, L.C.; Keim, B.D. Regional variation in perceptions about climate change. Int. J. Climatol. 2009, 29, 2348-2352. [CrossRef]

33. McCright, A.M.; Dunlap, R.E. The politicization of climate change and polarization in the American public's views of global warming, 2001-2010. Sociol. Q. 2011, 52, 155-194. [CrossRef]

34. Kim, S.; Kim, S. Analyzing the determinants of concern about and responses to climate change. Kor. J. Pub. Ad. 2016, 54, 179-206. [CrossRef]

35. Rokeach, M. The Nature of Human Values; Free Press: New York, NY, USA, 1973.

36. Douglas, M. Natural Symbols: Explorations in Cosmology; Barrie and Rockliff, Cresset Press: London, UK, 1970.

37. Douglas, M. Purity and Danger: An Analysis of Concepts of Pollution and Taboo; Routledge and Kegan Paul: London, UK, 1966.

38. Dake, K. Myths of nature: Culture and the social construction of risk. J. Soc. Issues 1992, 48, 21-37. [CrossRef]

39. Dake, K.; Wildavsky, A. Theories of risk perception: Who fears what and why? Daedalus 1990, 119, 41-60.

40. Bellamy, R.; Hulme, M. Beyond the tipping point: Understanding perceptions of abrupt climate change and their implications. Weather Clim. Soc. 2011, 3, 48-60. [CrossRef]

41. Truelove, H.B.; Joireman, J. Understanding the relationship between christian orthodoxy and environmentalism: The mediating role of perceived environmental consequences. Environ. Behav. 2009, 41, 806-820. [CrossRef]

42. Fischhoff, B.; Slovic, P.; Lichtenstein, S.; Read, S.; Combs, B. How safe is safe enough? A Psychometric study of attitudes towards technological risks and benefits. Policy Sci. 1978, 9, 127-152. [CrossRef]

43. Jankó, F.; Bertalan, L.; Hoschek, M.; Komornoki, K.; Németh, N.; Papp-Vancsó, J. Perception, understanding, and action: Attitudes of climate change in the Hungarian population. Hung. Geogr. Bull. 2018, 67, 159-171. [CrossRef]

44. Weber, E.U.; Stern, P.C. Public understanding of climate change in the United States. Am. Psychol. 2011, 66, 315-328. [CrossRef]

45. Johnson, M.F.; Hannah, C.; Acton, L.; Popovici, R.; Karanth, K.; Weinthal, E. Network environmentalism: Citizen scientists as agents for environmental advocacy. Glob. Environ. Chang. 2014, 29, 235-245. [CrossRef]

46. Kahan, D.M.; Peters, E.; Wittlin, M.; Slovic, P.; Ouellette, L.L.; Braman, D.; Mandel, G. The polarizing impact of science literacy and numeracy on perceived climate change risks. Nat. Clim. Chang. 2012, 2, 732-735. [CrossRef]

47. Prati, G.; Pietrantoni, L.; Albanesi, C. Human values and beliefs and concern about climate change: A Bayesian longitudinal analysis. Qual. Quant. 2018, 52, 613-1625. [CrossRef] [PubMed] 
48. Harring, N.; Jagers, S.C.; Matti, S. Public support for pro-environmental policy measures: Examining the impact of personal values and ideology. Sustainability 2017, 9, 679. [CrossRef]

49. O'Riordan, T. Environmental ideologies. Environ. Plan. A 1977, 9, 3-14. [CrossRef]

50. Borick, C.P.; Rabe, B.G. A reason to believe: Examining the factors that determine individual views on global warming. Soc. Sci. Q. 2010, 91, 777-800. [CrossRef]

51. Ikeme, J. Equity, environmental justice and sustainability: Incomplete approaches in climate change politics. Glob. Environ. Chang. 2003, 13, 195-206. [CrossRef]

52. Schlosberg, D.; Collins, L.B. From environmental to climate justice: Climate change and the discourse of environmental justice. WIREs Clim. Chang. 2014, 5, 359-374. [CrossRef]

53. Satterfield, T.A.; Mertz, C.K.; Slovic, P. Discrimination, vulnerability, and justice in the face of risk. Risk Anal. 2004, 24, 115-129. [CrossRef]

54. Leiserowitz, A.; Akerlof, K. Race, Ethnicity and Public Responses to Climate Change; Yale University and Yale Project on Climate Change; George Mason University: New Haven, CT, USA, 2010; Available online: http:/ / environment.yale.edu/uploads/RaceEthnicity2010.pdf (accessed on 2 February 2019).

55. Woodrum, E.; Hoban, T. Theology and religiosity effects on environmentalism. Rev. Relig. Res. 1994, 35, 193-206. [CrossRef]

56. Sachdeva, S. Religious Identity, Beliefs, and Views about Climate Change. Oxford Research Encyclopedia of Climate Science; Oxford University Press: Oxford, UK, 2016; Available online: http://oxfordre.com/ climatescience/view/10.1093/acrefore/9780190228620.001.0001/acrefore-9780190228620-e-335 (accessed on 28 January 2019).

57. Eckberg, D.L.; Blocker, T.J. Christianity, environmentalism, and the theoretical problem of fundamentalism. J. Sci. Study Relig. 1996, 35, 343-355. [CrossRef]

58. Woodrum, E.; Wolkomir, M.J. Religious effects on environmentalism. Sociol. Spectr. 1997, 17, $223-234$. [CrossRef]

59. Greenley, A. Religion and attitudes towards the environment. J. Sci. Study Relig. 1993, 32, 19-29. [CrossRef]

60. Deane-Drummond, C. Environmental justice and the economy: A Christian theologian's view. Ecotheology J. Relig. Nat. Environ. 2006, 11. [CrossRef]

61. Peterson, A. In and of the world? Christian theological anthropology and environmental ethics. J. Agric. Environ. Eth. 2000, 12, 237-261. [CrossRef]

62. Enderle, G. In search of a common ethical ground: Corporate environmental responsibility from the perspective of Christian environmental stewardship. J. Bus. Eth. 1997, 16, 173-181. [CrossRef]

63. Kearns, L. Saving the creation: Christian environmentalism in the United States. Sociol. Relig. 1996, 57, 55-70. [CrossRef]

64. Grizzle, R.E.; Barrett, C.B. The one body of Christian environmentalism. Zygon® 1998, 33, 233-253. [CrossRef]

65. Knez, I. Is climate change a moral issue? effects of egoism and altruism on pro-environmental behavior current. Urban Stud. 2016, 4, 157-174. [CrossRef]

66. Schwartz, S.H. Normative explanations of helping behavior: A critique, proposal, and empirical test. J. Exp. Soc. Psychol. 1973, 9, 349-364. [CrossRef]

67. Schwartz, S.H. Normative Influences on Altruism. Adv. Exp. Soc. Psychol. 1977, 10, 221-279.

68. Stern, P.C. Towards a coherent theory of environmentally significant behavior. J. Soc. Issues 2000, 56, 407-424. [CrossRef]

69. Clayton, S. New ways of thinking about environmentalism: Models of justice in the environmental debate. J. Soc. Issues 2000, 56, 459-474. [CrossRef]

70. Behrens, K.G. An African relational environmentalism and moral considerability. Environ. Eth. 2014, 36, 63-82. [CrossRef]

71. Smith, A.; Pulver, S. Ethics-based environmentalism in practice: Religious-environmental organizations in the United States. Worldviews Glob. Relig. Cult. Ecol. 2009, 13, 145-179. [CrossRef]

72. Arvesen, A.; Bright, R.M.; Hertwich, E.G. Considering only first-order effects? how simplifications lead to unrealistic technology optimism in climate change mitigation. Energy Policy 2011, 39, 7448-7454. [CrossRef]

73. Mitchell, R.B. Technology is not enough: Climate change, population, affluence, and consumption. J. Environ. Dev. 2012, 21, 24-27. [CrossRef]

74. Goldberg, J.; Marshall, N.; Birtles, A.; Case, P.; Curnock, M.; Gurney, G. On the relationship between attitudes and environmental behaviours of key Great Barrier Reef user groups. Ecol. Soc. 2018, 23, 19. [CrossRef] 
75. Bain, P.G.; Hornsey, M.J.; Bongiorno, R.; Jeffries, C. Promoting pro-environmental action in climate change deniers. Nat. Clim. Chang. 2012, 2, 600-603. [CrossRef]

76. Carlton, S.J.; Jacobson, S.K. Climate change and coastal environmental risk perceptions in Florida. J. Environ. Manag. 2013, 130, 32-39. [CrossRef]

77. Steg, L.; Sievers, I. Cultural theory and individual perceptions of environmental risks. Environ. Behav. 2000, 32, 250-269. [CrossRef]

78. Lee, T.M.; Markowitz, E.M.; Howe, P.D.; Ko, C.Y.; Leiserowitz, A.A. Predictors of public climate change awareness and risk perception around the world. Nat. Clim. Chang. 2015, 5, 1014-1020. [CrossRef]

79. Stevenson, K.T.; Peterson, M.N.; Bondell, H.D.; Moore, S.E.; Carrier, S.J. Overcoming skepticism with education: Interacting influences of worldview and climate change knowledge on perceived climate change risk among adolescents. Clim. Chang. 2014, 126, 293-304. [CrossRef]

80. O'Connor, R.E.; Bard, R.J.; Fisher, A. Risk perceptions, general environmental beliefs, and willingness to address climate change. Risk Anal. 1999, 19, 461-471. [CrossRef]

81. Drews, S.; Van den Bergh, J.C. What explains public support for climate policies? A review of empirical and experimental studies. Clim. Policy 2016, 16, 855-876. [CrossRef]

82. Hausmann, A.; Slotow, R.; Burns, J.K.; Di Minin, E. The ecosystem service of sense of place: Benefits for human well-being and biodiversity conservation. Environ. Conserv. 2016, 43, 117-127. [CrossRef]

83. Demuzere, M.; Orru, K.; Heidrich, O.; Olazabal, E.; Geneletti, D.; Orru, H.; Bhave, A.G.; Mittal, N.; Feliu, E.; Faehnle, M. Mitigating and adapting to climate change: Multi-functional and multi-scale assessment of green urban infrastructure. J. Environ. Manag. 2014, 146, 107-115. [CrossRef]

84. Milfont, T.L. The interplay between knowledge, perceived efficacy, and concern about global warming and climate change: A one-year longitudinal Study. Risk Anal. 2012, 32, 1003-1020. [CrossRef] [PubMed]

85. Lubell, M.; Zahran, S.; Vedlitz, A. Collective action and citizen responses to global warming. Political Behav. 2007, 29, 391-413. [CrossRef]

86. Levi, M.; Stoker, L. Political trust and trustworthiness. Annu. Rev. Political Sci. 2000, 3, 475-507. [CrossRef]

87. Dalton, R.J. Democratic Challenges, Democratic Choices: The Erosion of Political Support in Advanced Industrial Democracies; Oxford University Press: Oxford, UK, 2004.

88. Paul, C.J.; Weinthal, E.S.; Bellemare, M.F.; Meuland, M.A. Social capital, trust, and adaptation to climate change: Evidence from rural Ethiopia. Glob. Environ. Chang. 2016, 36, 124-138. [CrossRef]

89. Arbuckle, J.G.; Morton, L.W.; Hobbs, J. Understanding farmer perspectives on climate change adaptation and mitigation: The roles of trust in sources of climate information, climate change beliefs, and perceived risk. Environ. Behav. 2015, 47, 205-234. [CrossRef]

90. Smith, E.K.; Mayer, A. A social trap for the climate? collective action, trust and climate change risk perception in 35 countries. Glob. Environ. Chang. 2018, 49, 140-153. [CrossRef]

91. Slovic, P. Perception of risk. Science 1987, 236, 280-285. [CrossRef]

92. Muis, K.R.; Pekrun, R.; Sinatra, G.M.; Azevedo, R.; Trevors, G.; Meier, E.; Heddy, B.C. The curious case of climate change: Testing a theoretical model of epistemic beliefs, epistemic emotions, and complex learning. Learn. Instr. 2015, 39, 168-183. [CrossRef]

93. Wang, S.; Leviston, Z.; Hurlstone, M.; Lawrence, C.; Walker, I. Emotions predict policy support: Why it matters how people feel about climate change. Glob. Environ. Chang. 2018, 50, 25-40. [CrossRef]

94. O'Neill, S.; Nicholson-Cole, S. "Fear won't do it": Promoting positive engagement with climate change through visual and iconic representations. Sci. Commun. 2009, 30, 355-379. [CrossRef]

95. Lewis, K.H.; Lenton, T.M. Knowledge problems in climate change and security research. Wiley Interdiscip. Rev. Clim. Chang. 2015, 6, 383-399. [CrossRef]

96. Tàbara, J.D.; Clair, A.L.S.; Hermansen, E.A. Transforming communication and knowledge production processes to address high-end climate change. Environ. Sci. Policy 2017, 70, 31-37. [CrossRef]

97. Reyes-García, V.; Fernández-Llamazares, Á.; Guèze, M.; Garcés, A.; Mallo, M.; Vila-Gómez, M.; Vilaseca, M. Local indicators of climate change: The potential contribution of local knowledge to climate research. Wiley Interdiscip. Rev. Clim. Chang. 2016, 7, 109-124. [CrossRef] [PubMed]

98. Bord, R.J.; O'Connor, R.E.; Fisher, A. In what sense does the public need to understand global climate change? Public Underst. Sci. 2000, 9, 205-218. [CrossRef]

99. Liu, S.; Roehrig, G.; Bhattacharya, D.; Varma, K. In-Service teachers' attitudes, knowledge and classroom teaching of global climate change. Sci. Educ. 2015, 24, 12-22. 
100. Bord, R.J.; O'Connor, R.E. The gender gap in environmental attitudes: The case of perceived vulnerability to risk. Soc. Sci. Q. 1997, 78, 830-840.

101. McCright, A.M. The effects of gender on climate change knowledge and concern in the American public. Popul Environ. 2010, 32, 66-87. [CrossRef]

102. Reinhart, R.J. Global Warming Age Gap: Younger Americans Most Worried. Politics, 11 May 2018. Available online: https:/ / news.gallup.com/poll/234314/global-warming-age-gap-younger-americans-worried.aspx (accessed on 2 February 2019).

103. Hamilton, L.C. Education, politics and opinions about climate change evidence for interaction effects. Clim. Chang. 2011, 104, 231-242. [CrossRef]

104. Tranter, B. Political divisions over climate change and environmental issues in Australia. Environ. Political 2011, 20, 78-96. [CrossRef]

105. Gifford, R.; Nilsson, A. Personal and social factors that influence pro-environmental concern and behaviour: A review. Int. J. Psychol. 2014, 49, 141-157. [CrossRef] [PubMed]

106. Torgler, B. Tax morale, rule-governed behaviour and trust. Const. Political Econ. 2003, 14, 119-140. [CrossRef]

107. Baron, R.M.; Kenny, D.A. The Moderator-Mediator variable distinction in social psychological research: Conceptual, strategic, and statistical considerations. J. Personal. Soc. Psychol. 1986, 51, 1173-1182. [CrossRef]

108. Huh, B.; Li, Y.E.; Weber, E. A Finite Pool of Worry. In Advances in Consumer Research; Moreau, P., Puntoni, S., Eds.; Association for Consumer Research: Duluth, MN, USA, 2016; p. 737.

109. Kim, S. Irresolvable cultural conflicts and conservation/development arguments: Analysis of Korea's Saemangeum project. Policy Sci. 2003, 36, 125-149. [CrossRef]

110. Wang, J.; Kim, S. Analysis of the impact of values and perception on climate change skepticism and its implication for public policy. Climate 2018, 6, 99. [CrossRef]

111. Kim, S.; Kim, S. Exploring the effect of four factors on affirmative action program for women. AJWS 2014, 20, 31-70. [CrossRef]

112. Kim, S.; Kim, S. Impact of the Fukushima nuclear accident on belief in rumors: The role of risk perception and communication. Sustainability 2017, 9, 2188. [CrossRef]

113. Wang, J.; Kim, S. Comparative analysis of public attitudes toward nuclear power energy across 27 European countries by applying the multilevel model. Sustainability 2018, 10, 1518. [CrossRef]

114. Kim, S.; Kim, D. Does government make people happy? Exploring new research directions for government's roles in happiness. J. Happiness Stud. 2012, 13, 875-899. [CrossRef]

115. Kim, S.; Choi, S.; Wang, J. Individual perception vs. structural context: Searching for multilevel determinants of social acceptance of new science and technology across 34 countries. Sci. Public Policy 2014, 41, 44-57. [CrossRef]

116. Kim, S.; Kim, S. Exploring the determinants of perceived risk of Middle East Respiratory Syndrome (MERS) in Korea. Int. J. Environ. Res. Public Health 2018, 15, 1168. [CrossRef] [PubMed]

117. Wang, J.; Kim, S. Searching for new directions for energy policy: Testing the cross-effect of risk perception and cyberspace factors on online/offline opposition to nuclear energy in South Korea. Sustainability 2019, 11, 1368. [CrossRef]

(C) 2019 by the authors. Licensee MDPI, Basel, Switzerland. This article is an open access article distributed under the terms and conditions of the Creative Commons Attribution (CC BY) license (http://creativecommons.org/licenses/by/4.0/). 